\title{
Is the comb jelly really to blame for it all? Mnemiopsis leidyi and the ecological concerns about the Caspian Sea
}

\author{
Martin Bilio $^{1, *}$, Ulrich Niermann ${ }^{2}$ \\ ${ }^{1}$ Am Hirschsprung 10, 61462 Königstein, Germany \\ ${ }^{2}$ Am Sackenkamp 37, 23374 Heiligenhafen, Germany
}

\begin{abstract}
The appearance in 1995 of the alien ctenophore Mnemiopsis leidyi in the Caspian Sea attracted considerable attention. In 1989, enormous mass development of the comb jelly in the Black Sea coincided with a breakdown of the commercially highly important anchovy Engraulis encrasicholus fishery in this area. This collapse probably resulted from multiple factors, among which overfishing and food competition from the ctenophore played a prominent role, enhanced by predation of $M$. leidyi on the early life stages of the anchovy. The abundance of food due to the depletion of the anchovy stock permitted a population explosion of $M$. leidyi. Subsequently, reduced fishing pressure allowed recovery of the anchovy stock and led to a new peak in anchovy landings in the Black Sea in 1995. Moreover, changes in the atmospheric and oceanic patterns in the northern hemisphere in the second half of the 1980s could have altered the composition of the phyto- and zooplankton communities and thus the food base of the small pelagic fish species. In the second half of the 1990s, the invasion of the Black Sea by another alien ctenophore, Beroe ovata, preying on ctenophores, raised hopes that this species could control $M$. leidyi. However, it is uncertain whether the preying capacity of $B$. ovata is sufficient to control $M$. leidyi in other than locally favourable conditions. At the present time, judging by the recent development in the Black Sea, the invasion of the Caspian Sea by $M$. leidyi does not yet seem to have reached maximum intensity. More consistent and comparable investigations in the Caspian and Black Seas are necessary to improve the protection, management and exploitation of the stocks of small pelagic fishes, in order to increase their capacity to resist and survive unforeseeable disturbances of their ecosystem by invaders such as $M$. leidyi. In view of the new invasion by this ctenophore, research into the exploitation of the Caspian kilka Clupeonella spp. stocks and the influence of atmospheric teleconnection patterns on ecological conditions in the Caspian Sea is of particular importance.
\end{abstract}

KEY WORDS: Bioinvasion · Caspian Sea $\cdot$ Black Sea $\cdot$ Ctenophores $\cdot$ Mnemiopsis leidyi $\cdot$ Beroe ovata Anchovy fishery $\cdot$ Kilka fishery $\cdot$ Regime shift

\section{INTRODUCTION}

With growing worldwide interest in the oil and gas reserves of the Caspian region, the ecological problems of the area are also receiving increased attention. Due to its position in the far southeast of Europe, little information about the region was available in the West until recently, and it was not until a few years ago that the public became aware of the potential disaster threatening the unique ecosystem of the Caspian Sea and its immediate surroundings (Dumont 1995). Stone
(2002) described most of the acute problems in this area: reduction of the river run-off reaching the Caspian Sea caused by damming the main tributary, the Volga river; the unstable water level; the various sources of pollution; the over-utilisation of its living resources (in particular the sturgeon species); and, finally, the threat to the entire system posed by a new invader, the ctenophore Mnemiopsis leidyi.

The present study focuses on the recent appearance of this exotic ctenophore in the Caspian Sea and attempts a balanced evaluation of the effects of its invasion of the 
Black and Caspian Seas. Our main aim was to determine what can be learned from its invasion of the Black Sea which could be applied to the Caspian Sea, and to this end we thoroughly reviewed all relevant data publicly available.

Ecologists have become increasingly familiar with the ecological threats arising from the accidental spread of organisms by ever-increasing intercontinental traffic and the potential danger associated with the introduction of imported organisms (e.g. with ballast water). Mnemiopsis leidyi is indigenous to the east coast of the Americas, and was probably transported first to the Black Sea and then to the Caspian Sea in ballast water. The impact of such immigrants on the native fauna and flora is complex. In the case of M. leidyi,

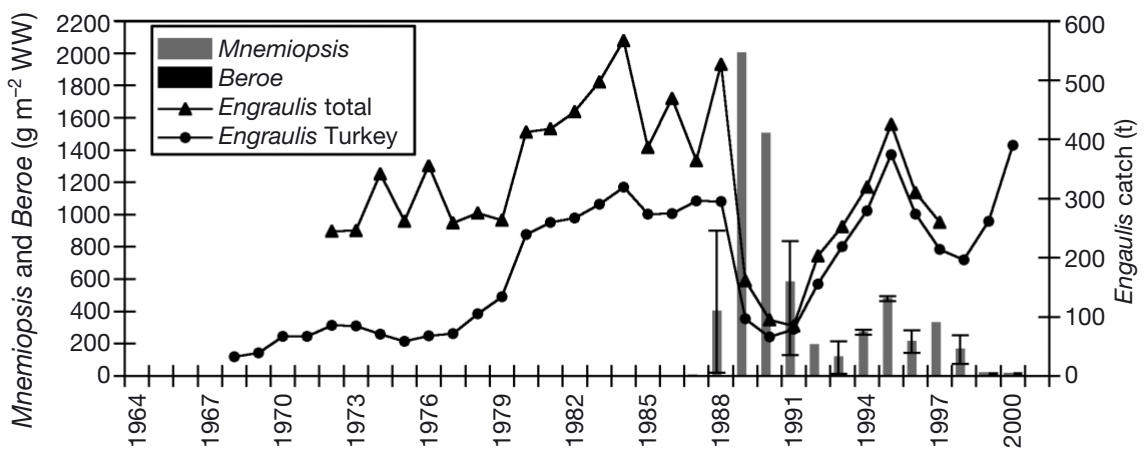

Fig. 1. Biomass of Mnemiopsis leidyi and Beroe ovata (sensu Mayer) in offshore waters of the Black Sea and the Engraulis encrasicholus catch of the total Black Sea and the Turkish area. Biomass of M. leidyi and B. ovata in 1999 was $12 \mathrm{~g} \mathrm{~m}^{-2}$ for both species, and in 2000 it was 11 and $12 \mathrm{~g} \mathrm{~m}^{-2}$, respectively. Vertical lines in the $M$. leidyi bars indicate (where available) the range of the minimum and maximum averages of the different surveys of one year. Data for M. leidyi from Kideys \& Romanova (2001), and for B. ovata from Kideys (pers. comm.); total anchovy catch according to the FAO (Food and Agriculture Organization of the UN), Turkish data from DIE (Turkish State Institute of Statistics) (1968-2000). WW: wet wt opinions on its actual and probable im-

pact were, and still are, divided. The species first appeared in the Black Sea in 1982; several years later (in 1989) a drastic decline in an important fishery resource, the anchovy Engraulis encrasicholus, occurred and was connected with the simultaneous population explosion of $M$. leidyi. As a consequence, pressure built up to counteract the invasion with a deliberate introduction of predators known to feed on gelatinous organisms.

\section{HISTORICAL FEATURES}

Many aspects of the invasion of the Black Sea and adjacent areas of the Mediterranean by Mnemiopsis leidyi are discussed in a publication by a group of experts on the scientific aspects of marine pollution (GESAMP 1997), which reports that $M$. leidyi was first detected in the Black Sea in 1982, in the Asov Sea in 1988, and outside the Black Sea in northeastern areas of the Mediterranean in 1992 and 1993 (see their Table 2). The first dramatic outbreak of the $M$. leidyi population in the Black Sea occurred in 1989, with an increase in offshore biomass from $225 \mathrm{~g}$ wet wt $\mathrm{m}^{-2}$ in early 1988 to $2000 \mathrm{~g} \mathrm{~m}^{-2}$ in 1989 recorded by Mutlu et al. (1994) (see also Fig. 1, present study), and from $1000 \mathrm{~g}$ wet wt m${ }^{-2}$ in September 1988 to $4600 \mathrm{~g} \mathrm{~m}^{-2}$ in 1989 recorded by Shiganova et al. (2001b). For spring 1990, values as high as 11 to $12 \mathrm{~kg} \mathrm{~m}^{-2}$ were reported for coastal waters off Bulgaria (Shushkina \& Vinogradov 1991). High biomasses of M. leidyi (569 to $836 \mathrm{~g} \mathrm{~m}^{-2}$ ) were still recorded in spring 1991 in Turkish and Russian areas, but by June biomass had collapsed to little more than $100 \mathrm{~g} \mathrm{~m}^{-2}$ in Turkish offshore waters (Shushkina \& Vinogradov 1991, Mutlu et al. 1994).
When the GESAMP (1997) report was prepared (1994/1995), the further course of development and distribution of Mnemiopsis leidyi in the invaded region was not known, and some of the conclusions drawn then must be reconsidered in the light of new data (Fig. 1). In April 2001, Shiganova (2001b) summarised what was known about the further development of $M$. leidyi in the Black Sea and other parts of the northeastern Mediterranean. This and Turkish data (Mutlu 1999, Kideys \& Romanova 2001, Kideys: www. caspianenvironment.org/mnemiopsis/mnem_attach8. htm) indicated that a second $M$. leidyi biomass peak occurred in the Black Sea in 1995 (i.e. 6 yr after the first peak) that was $>50 \%$ the level of the first peak (2700 g $\mathrm{m}^{-2}$ in 1995 compared to $4600 \mathrm{~g} \mathrm{~m}^{-2}$ in 1989) in Russian offshore waters (Shiganova et al. 2001b) and 25\% of the 1989 level in Turkish waters (Kideys \& Romanova 2001) (see Fig. 1). However, a maximum of $9700 \mathrm{~g} \mathrm{~m}^{-2}$ (average: $4500 \mathrm{~g} \mathrm{~m}^{-2}$ ) was observed in Russian inshore waters in September 1994 (Shiganova et al. 2001b). ${ }^{1}$

By 1999, the biomass of the ctenophore in Turkish offshore waters had decreased close to zero, the decrease being accompanied by the appearance of another ctenophore, Beroe sp., which feeds on ctenophores and had first been observed in 1997 by Konsulov \& Kamburska (1998a). This species was believed also to be of American origin, and it has recently been suggested that it be provisionally called B. ovata sensu Mayer, as opposed to the synonymous

\footnotetext{
${ }^{1}$ In inshore waters, local accumulations, caused by the configuration of the coastline and special current patterns, can considerably exceed the densities of the same plankton organisms in the open sea
} 
Mediterranean species B. ovata sensu Chun (R. Harbison \& K. Bayha pers. comm.). Seravin et al. (2002) have now described the Black Sea form definitively as $B$. ovata sensu Mayer.

In the Caspian Sea, according to Negarestan et al. (www.caspianenvironment.org/mnemiopsis/mnem attach13.htm), Mnemiopsis leidyi was first recorded in Iranian waters in 1995 by the Iranian Fisheries Research Organization. An observation of 'strange jellies' by Turkmenian fishermen in 1996 would correspond to the Iranian record, but could not be scientifically confirmed (Ivanov et al. 2000). It appears probable that the ctenophore made its way from the Black Sea to the Caspian Sea through the Volga-Don canal, again in ballast water.

Ivanov et al. (2000) recorded the species on a coastal plateau along the east coast of the central part of the Caspian Sea in November 1999. In 2000, the distribution of Mnemiopsis leidyi in the Caspian Sea was studied during 4 cruises organised by KaspNIIRKh (the Caspian Scientific Fishery Research Institute in Astrakhan) from July to October (Shiganova et al. 2001a). In July the species was abundant in the central Caspian and in the northern part of the south Caspian Sea, but in the north Caspian Sea it was first recorded only in September. Its lower salinity limit appears to be 4 to $6 \mathrm{ppt}$, and it was recorded at salinities within this range in the vicinity of the Volga delta. In the northern study area, its average abundance in October was 108 ind. $\mathrm{m}^{-2}$ and its average biomass $140 \mathrm{~g} \mathrm{~m}^{-2}$. From July to October 2000, a considerable decrease in the abundance and biomass of all zooplankton, particularly copepods, occurred. Kideys \& Moghim (2003) reported on the results of a cruise in the central and southern Caspian Sea in August 2001, when M. leidyi was recorded ubiquitously, with its highest biomass in the southern part of the central Caspian and along its west coast (max. $352 \mathrm{~g}$ $\mathrm{m}^{-2}$ ) and its highest abundance in Russian, Azeri and Iranian coastal waters (max. 2285 ind. $\mathrm{m}^{-2}$; Fig. 2), but not in offshore waters. The presence of many small individuals led Kideys \& Moghim (2003) to consider the western coastal areas reproductive 'hot spots', the formation of which was due to higher nutrient inputs from tributaries in the west relative to the east, resulting in better food conditions.

However, in the Caspian Sea, the period of observation (and especially the period of systematic observation) was too short to determine final tendencies in the spread and mass development of Mnemiopsis leidyi. An ongoing monitoring programme along the Iranian coasts seems to indicate that in 2002 this invader still might not have reached peak levels (A. Kideys pers. comm., T. Shiganova pers. comm.), which would correspond to the population development in the Black Sea, where the first (and highest) peak was reached in 1989 , i.e. 7 yr after the first recorded occurrence.
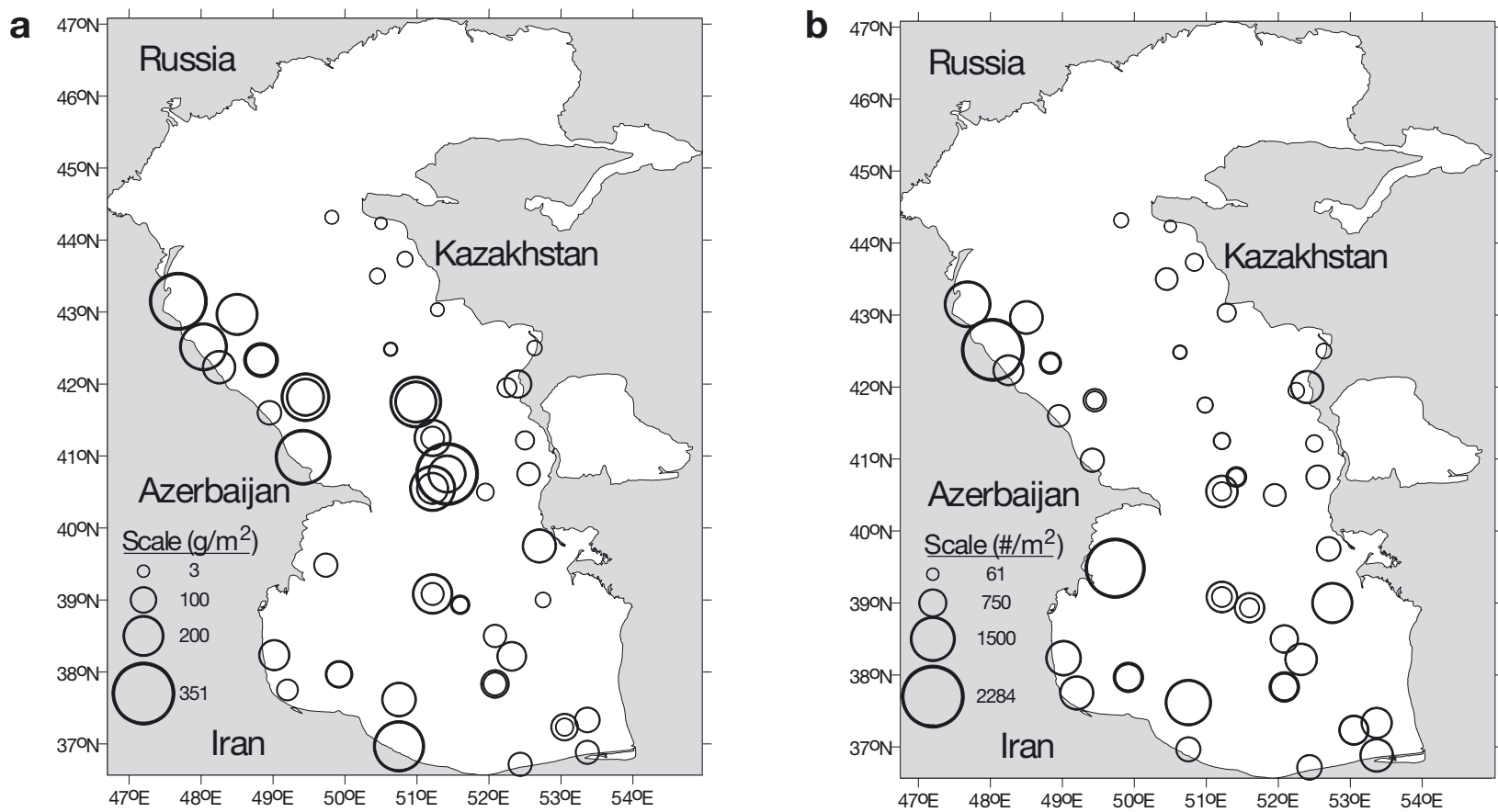

Fig. 2. Distribution of Mnemiopsis leidyi (a) biomass $\left(\mathrm{g} \mathrm{m}^{-2}\right.$ ) and (b) abundance (ind. $\mathrm{m}^{-2}$ ) in the Caspian Sea in August 2001. Biomass: smallest and largest circles indicate 3 and $351 \mathrm{~g} \mathrm{~m}^{-2}$, respectively; abundance: smallest and largest circles correspond to 61 and 2284 ind $\mathrm{m}^{-2}$, respectively. After Kideys \& Moghim (2003) 


\section{UPDATE OF BLACK SEA OCCURRENCE}

\section{Development of anchovy fishery}

The sharp decline in anchovy catches in 1989 and the simultaneous outbreak of Mnemiopsis leidyi in the Black Sea were considered to be strongly connected (Vinogradov et al. 1989, Shushkina \& Vinogradov 1991, Zaika 1993, GESAMP 1997 and citations therein). Little attention was given to the relatively long lag-time of $7 \mathrm{yr}$ from the first record (1982) to the population explosion (1989) of the ctenophore, and to its decrease in abundance in 1998 (see Fig. 1), with a second peak in 1995 reaching a much lower level than the first in 1989. Possible concurrent causes for the fishery decline, suggested by GESAMP (1997), were later largely ignored, with Stone (2002) referring to $M$. leidyi as 'notorious for having devastated anchovy populations in the Black Sea'.

On the basis of present data, the possible causes for the decline in the anchovy fishery in the Black Sea can be summarised as follows (Niermann in press): (1) Anchovy stock collapsed due to heavy predation by Mnemiopsis leidyi on fish eggs and larvae. (2) Heavy competition by $M$. leidyi for zooplankton caused the anchovy stock to starve. (3) Severe overfishing of the anchovy stock made its food available to the ctenophore, resulting in the latter's sudden population explosion. (4) A regime shift starting in the second half of the 1980s and affecting phyto- and zooplankton production triggered the decline in the anchovy stock as well as the bloom of the comb jelly.

\section{Hypothesis 1: Predation on fish eggs and larvae}

The first hypothesis immediately followed the 1989 outbreak. The abundance of anchovy eggs and larvae along the Crimean peninsula declined strongly compared to that in 1988 (Niermann et al. 1994 and citations therein). However, although it is well established that Mnemiopsis leidyi preys heavily upon anchovy eggs and larvae (Cowan \& Houde 1993), especially at the yolk-sac stage, this does not necessarily mean that the entire decline was due to $M$. leidyi predation. Tsikhon-Lukanina \& Reznitchenko (1991) and Tsikhon-Lukanina et al. (1991) have shown that this ctenophore feeds more intensively on copepods than on the eggs and larvae of fishes.

In addition, the drastic decline in the anchovy stock coincided with peak Mnemiopsis leidyi abundance. Had the ctenophore wiped out the early life-stages of the anchovy in the summer of 1989, then the collapse of the anchovy fishery would not have impacted until 1 to 2 yr later (i.e. 1990 and 1991), when the affected cohort would normally have developed into the ageclasses exploited by the fishery. The anchovy fishery takes place in winter, when the fish starts to form large schools. In their first winter, anchovies are too small (total length approx. $4 \mathrm{~cm}$ ) to be fished, but in the following July the cohort would normally mature and, in the subsequent winter, at a length of 8 to $11 \mathrm{~cm}$, become fishery recruits (F. Bingel pers. comm.). Since the decline in anchovy fishery occurred in 1989, abundance of $M$. leidyi sufficient to have this effect would have had to be recorded as early as in 1988, which apparently was not the case. The sequence of effects between mass occurrence of $M$. leidyi and catch decline of small pelagic fishes should be taken carefully into consideration for the Caspian Sea.

\section{Hypothesis 2: Food competition}

The second hypothesis appears to be more reasonable since, in 1989 to 1992, the high abundance of Mnemiopsis leidyi coincided with, and was followed by, a dramatic decrease in the mesozooplankton throughout the entire Black Sea (Konsulov \& Kamburska 1998b, Kovalev et al. 1998, Kideys et al. 2000, Goubanova et al. 2001), and the stock of another plankton-feeder, the sprat Sprattus sprattus on the north-western shelf of the Black Sea, showed signs of starvation (Shulman \& Yuvena 2002).

Stomach analyses of anchovy larvae (Tkach et al. 1998, their Table 2) revealed that in 1989 to 1991 the percentage of empty guts was very high in small larvae (<12 mm) compared to 1955 to 1965 , but less so for larger larvae (12 to $25 \mathrm{~mm}$ ). In addition, the species composition in the gut contents had changed: preferred food species, such as Oithona nana, had decreased or disappeared, while Acartia clausi, which is more difficult to swallow, had increased in abundance (Kovalev et al. 1998, Goubanova et al. 2001). According to Shulman \& Yuvena (2002), these changes in gut content are correlated with major changes in zooplankton composition after 1985, indicating a large-scale change in meteorological and oceanographic conditions (see 'Hypothesis 4', below). Preferred food species had disappeared, compelling the anchovy larvae to turn to less preferred food items (Gordina et al. 1998).

The deterioration of the food base of the anchovy described above, together with heavy trophic competition by Mnemiopsis leidyi, may thus have led to the drastic decline in the anchovy stock from 1989 to 1990 (Kideys et al. 2000). Kideys et al. (2000) assumed that trophic competition by $M$. leidyi first affected anchovy larvae feeding on smaller stages of the copepod Calanus euxinus, and subsequently adult anchovy 
feeding on later, larger stages of this copepod, thus contributing to the decrease in the anchovy catch in 1990, which was mainly attributable to low recruitment to the spawning stock during 1989 (see 'Hypothesis 3', below).

The available data is inadequate in 2 respects: (1) food preferences relating to type and size of preferred food items change with increasing development stage (e.g. anchovy larvae and adults feeding on different stages of Calanus euxinus); and (2) much of the published data concerns local areas and cannot be extrapolated to the Black Sea as a whole.

The sudden population explosion of Mnemiopsis leidyi and the simultaneous drastic decline in anchovy abundance were so striking that the 2 events were immediately related to each other. The concurrence of events may have led to an overestimation of the magnitude of the bloom due to inaccurate extrapolation. Extrapolation produced a biomass of about 840000000 $\mathrm{t}$ for the whole of the Black Sea, based on very high values recorded at 32 stations (Vinogradov et al. 1989), seemingly without much consideration being given to the known patchiness of the distribution of gelatinous zooplankton. This estimate made such an impression that it was subsequently often used as reference data to demonstrate the heavy impact of the ctenophore invasion on the standing stocks of mesozooplankton and larval fishes.

The use of the ecosystem model ECOPATH by Gücü \& Oguz (1998) and a critical review by Weisse et al. (2002) suggest that neither the carrying capacity nor the trophic structure of the Black Sea could support such a high biomass of Mnemiopsis leidyi. Modelling results of Gücü (2002) further revealed that much less zooplankton than that observed in situ would have supported the ecosystem in the late 1980s, indicating that there was enough food available for small pelagic fishes at the time of the collapse of the anchovy fishery (1989 to 1990). Long-term data from Shiganova \& Bulganova (2000) also seem to favour the hypothesis that, despite the changes in the spectrum of available food, adult anchovy had access to sufficient food even during the critical years of 1989 and 1990. If this is true, it is questionable whether food competition and predation on eggs and larvae were the only causes of the collapse of the anchovy fishery.

\section{Hypothesis 3: Overfishing}

The fisheries situation in the Black Sea in the 1980s was complicated by various factors. With regard to fishing pressure, one of the more incisive changes was a sharp reduction in exploitation at the end of the 1980s as a consequence of the economic decline of the former Soviet Union. At that time, the anchovy was mainly exploited by the Turkish fleet, which during 1980 to 1990 increased the number of its purse seiners from $\sim 120$ to $\sim 270$, and the number of boats equipped with sonar from 40 to 120 (Gücü 2002). It is possible, therefore, that the increased Turkish effort eventually overcompensated the reduction in the Soviet fishing effort.

According to Yu. Artemov (Institute of Biology of the Southern Seas, Sevastopol, pers. comm.; see also Niermann in press, Fig. 3), in the early 1980s there were already signs that fishing mortality was beginning to exceed anchovy recruitment in the northern Black Sea. Gücü (1997) found indications of overfishing when comparing the Turkish landings of 1988/1989 with those of the preceding fishing season (1987/88), reporting that fish caught in 1988/1989 were smaller than those caught in 1987/1988. The exploitation of the anchovy stock had already exceeded a sustainable level in 1987/1988, and in 1988/1989 the fleet, in an effort to maintain a catch level similar to that of the preceding years, caught mainly newly recruited, small fish and juveniles, i.e. individuals that had not attained sexual maturity. One year later, in 1989/1990, the Turkish catches had declined further to $66000 \mathrm{t}$ (Fig. 1). Shiganova (1997) stated that in 1988 the new anchovy generation comprised only a fourth of that in 1987, due to a decrease in the spawning stock caused by overfishing in 1987, and that overfishing was the main reason for the decline in anchovy in 1989.

An analysis of the gonadosomatic index of the anchovy in Turkish waters before and after the collapse of the fishing industry (Gücü 1997) showed that at the time of the collapse, the newly recruited anchovies were in better condition than before the collapse. This is not surprising as, with the depletion of the anchovy stock, food availability increased for the remaining anchovy and other planktivorous organisms. The real reason for the anchovy decline thus appears to be a recruitment failure arising from overfishing even before 1988 (Gücü 1997). Long-term data (1951 to 1990) of various authors on the gut fullness (summarised by Shiganova \& Bulganova 2000) point to the same cause: especially the anchovy had sufficient available food before and at the time of the collapse of its fishery (see also earlier subsection 'Hypothesis 2').

Since much of the mesozooplankton was no longer being utilised by one of its major consumers (the nowdepleted anchovy stock), it thus became more easily available to Mnemiopsis leidyi, which consequently experienced unprecedented increase (Prodanov 1997, Gücü 2002). Once established, M. leidyi displaced anchovy during the subsequent 2 yr, i.e. until 1992, when, as a result of the reduced fishing pressure, the anchovy stock again increased (Fig. 1). According to Gücü (2002), 
a sufficiently large stock of small pelagic fishes can successfully compete with the ctenophore for the same food resources, since they are quicker and more active.

The possible role of fish stock depletion due to overfishing should, therefore, be carefully considered at the first signs of an invasion by a new jellyfish, especially when such an invasion threatens to develop into a massive outbreak.

\section{Hypothesis 4: Regime shift}

With ever-increasing opportunities for comparing local or regional oceanographic and meteorological phenomena on a world-wide level, more and more synchronous events and developments are being discovered and analysed (e.g. the El Niño phenomenon). The term 'regime shift' is used to describe large decadal-scale switches in the abundance and composition of plankton and fish communities (Hare et al. 2000). A comparison of the long-term fluctuations in the plankton and anchovy populations of the Black Sea with fluctuations in other regions (e.g. North Atlantic, North and Baltic Seas, European freshwater lakes) revealed striking similarities, and led Niermann et al. (1999) to hypothesise that the changes in the Black Sea at the end of the 1980s could, indeed, be linked to large-scale meteorological phenomena.

Recurring and persistent large-scale patterns of pressure and circulation anomalies that span vast geographical areas are referred to as 'teleconnection patterns' (Rodionov 1994, NOAA: www.cpc.ncep.noaa. gov/data/teledoc/teleintro.html). How could such teleconnections have contributed to the collapse of the anchovy fishery in the Black Sea and the simultaneous outbreak of Mnemiopsis leidyi? Anthropogenic environmental changes which have occurred since the end of the 1960s (pollution, eutrophication, irrigation, damming, overfishing) may have caused the pelagic ecosystem to become increasingly unstable, with a changed prey-predator relationship (Moncheva \& Krastev 1997, Zaitzev \& Mamaev 1997, Bodeanu in press), so that $M$. leidyi, already favoured by the altered trophic structure of the system, required only a certain trigger for a population explosion. The trigger could have been overfishing, and/or a climatic signal such as the superimposition of different meteorological, hydrological and biological cycles, or events that occurred during or at the end of the 1980s, as indicated by a steep rise in the NAO (North Atlantic Oscillation Index, i.e. difference in air pressure between the Azores high and the Iceland low; Niermann 1999 and citations therein).

At the end of the 1980s, striking changes in the hydrological and meteorological regime (sea and air temperature, salinity, atmospheric pressure, strength of westerly winds, precipitation, river run-off) were, indeed, observed in the northern hemisphere from the North Atlantic to the Black and Caspian Seas (Rodionov 1994, Osoy \& Ünlüata 1997, Reid \& Edwards 2001, Stanev \& Peneva 2002). These changes in regime could have caused changes in the phyto- and mesozooplankton communities, thus compromising the food base of small pelagic fishes such as the Black Sea anchovy (Niermann et al. 1999, Yunev et al. 2002, Oguz et al. 2003).

Interesting in this respect is a comparison of the Black Sea with the Mediterranean Sea, in which all anchovy stocks displayed pronounced fluctuations similar to those in the Black Sea, although with a slight time lag (Oliver: www.faocopemed.org/vldocs/0000487/hnd_4.5.3.1.pdf). In all areas of the Mediterranean as well as the Black Sea, the stock collapsed in a similar manner, following a short period of high exploitation. Except for the Balearic Islands, where catches have not recovered, all landings, including those of the Black Sea, increased again at the beginning of the 1990s (Oliver: see URL above). No mass occurrences of jellyfish were reported that could have been directly related to a collapse of one of the Mediterranean anchovy stocks.

Long-term records show that anchovy stocks fluctuate strongly irrespective of the presence of jellyfish blooms. In the Adriatic Sea, blooms of the scyphomedusa Pelagia noctiluca were observed in the periods 1976 to 1986 and 1994 to 1997 (Purcell et al. 1999, Mills 2001). The anchovy catches were lowest in the period 1987 to 1993, when no jellyfish blooms were noted. Only in the Black Sea did the decline in the anchovy fishery coincide with a mass occurrence of the accidentally introduced Mnemiopsis leidyi. Comparison of anchovy catches in different upwelling systems around the world revealed that anchovy stocks in South Africa (Shelton et al. 1993), the Benguela Current and California (Hunter \& Alheit 1995) all collapsed at about the same period, but with no impact of jellyfish reported.

Anchovy occupy a low trophic level, feeding chiefly on zooplankton. Anchovy larvae greatly depend on particular groups of phytoplankton such as diatoms (Lasker 1988). Anchovy are thus highly dependent on annual fluctuations in the seasonal phyto- and zooplankton blooms. This dependence is one of the reasons for the high annual fluctuations in the anchovy stocks themselves. Anchovy landings in different parts of the Mediterranean and in the Black Sea reflect the characteristic fluctuations in abundance of this species (Niermann in press).

Since anchovies spawn in their second year of life, there is always a danger of recruitment losses due to the inclusion of slightly smaller, immature stages in catches. The anchovy stock can, therefore, easily become overfished if the minimum fish length restriction is not respected. 
To date, the 'regime shift' hypothesis is still based mainly on the observation of synchronous events, and is characterised by a number of uncertainties that can only be removed through continued and increased research efforts. Such investigations should be extended to the Caspian Sea, for which pertinent meteorological and hydrological data were recorded and evaluated by Rodionov (1994).

In summary, the available Black Sea data indicate that overfishing of the anchovy stock in combination with regime-induced changes in the phyto- and zooplankton composition made it possible for Mnemiopsis leidyi to compete successfully for food, and also to decimate the early life stages of the anchovy stock. It is, therefore, important that the state of exploitation of the Caspian kilka (Clupeonella spp.) stocks be assessed as soon as possible.

\section{Appearance of Beroe ovata}

The second exotic ctenophore to appear in the Black Sea was Beroe ovata (sensu Mayer; see subsection 'Historical features' above), which was found off the Turkish and Bulgarian coasts in 1997. Its first mass occurrence (when it reached a wet biomass of $130 \mathrm{~g} \mathrm{~m}^{-2}$ ) was observed in autumn 1999 in northeastern inshore waters of the Black Sea (Vinogradov et al. 2000). In Russian and Ukrainian waters, detailed studies were conducted on the biology and ecology of both Mnemiopsis leidyi and B. ovata. Despite the short observation period, rather optimistic conclusions concerning the potential of $B$. ovata to control $M$. leidyi were drawn. However, some observations (e.g. about the density dependence of the controlling effect) discussed in this subsection qualify such conclusions.

According to Finenko et al. (www.caspianenvironment.org/mnemiopsis/mnem_attach6.htm), the biomass of Mnemiopsis leidyi in Ukrainian waters attained a maximum of $600 \mathrm{~g} \mathrm{~m}^{-2}$ in August 1995 and $210 \mathrm{~g} \mathrm{~m}^{-2}$ in September 2000 (just before the seasonal appearance of Beroe ovata). In Crimean coastal waters the spring biomass of $M$. leidyi in 1999 was also less than in 1995. As the first mass occurrence of B. ovata was observed in August 1999 (Vinogradov et al. 2000), it seems that the latter arrived at a time when the $M$. leidyi population had already been reduced by other factors. This does not contradict the statement of Finenko et al. (2003) that in 1999 and 2000 B. ovata 'appeared in (the) moment of maximum M. leidyi biomass' (which probably was a seasonal, not an annual maximum), because at this time the annual maximum M. leidyi biomass had already decreased from $600 \mathrm{~g}$ $\mathrm{m}^{-2}$ (August 1995) to $210 \mathrm{~g} \mathrm{~m}^{-2}$ (September 2000) (Finenko et al.; see URL above).
However, this qualification does not diminish the importance of the observations of an effective predation of Beroe ovata on Mnemiopsis leidyi, but must be integrated into a more differentiated picture. Indeed, in 2000 and 2001 the controlling effect of B. ovata on $M$. leidyi became more evident. In Sevastopol Bay, large numbers of $M$. leidyi occurred in August and September, while in October B. ovata was dominant (Finenko et al. 2003). This is in line with findings in the German Bight, where a developing bloom of the ctenophore Pleurobrachia pileus was effectively superseded by B. gracilis preying on P. pileus (Greve 1981).

Another question arises from a comparison of the preying efficiency of Beroe ovata on Mnemiopsis leidyi at different prey-predator density ratios (Vostokov et al. 2001). At a M. leidyi:B. ovata ratio of 1:2 (Golubaya Bay, nearshore waters of the Russian northeast coast of the Black Sea, October 1999), average-sized B. ovata were capable of consuming the entire $M$. leidyi population in $1 \mathrm{~d}$. At a density ratio of 25:1 (open sea, August and September 1999), B. ovata consumed only 0.5 to $5.7 \%$ of the $M$. leidyi biomass (observations and calculations by Vostokov et al. 2001). The question is, therefore, how does $B$. ovata control $M$. leidyi under the conditions of an extensive open sea area? According to in vitro studies by Finenko et al. (2003), B. ovata requires a food uptake representing $>20 \%$ of its body weight (wet wt) to grow, reaching a growth rate of $0.1 \mathrm{~d}^{-1}$ at a food-uptake rate of about $75 \%$ of its body weight.

The Black Sea observation that Beroe ovata can effectively prey on Mnemiopsis leidyi has encouraged the scientific community to consider predation by $B$. ovata as a possible solution for the incipient $M$. leidyi problem in the Caspian Sea, be it through accidental penetration of $B$. ovata through the Volga-Don Canal or through deliberate introduction (see 'Control measures' section below).

\section{INVASION OF THE CASPIAN SEA}

As the first record of Mnemiopsis leidyi in the Caspian Sea only dates back to 1995, much of what has been said about the consequences to be expected from the penetration of this comb jelly into the Caspian Sea is speculative. The conclusions drawn from the Black Sea observations, accumulated over $20 \mathrm{yr}$, are of limited value because (1) differences in geographical, hydrological, biological and palaeohistorical features allow only limited extrapolation, and (2) the coincidence of the $M$. leidyi invasion and the sudden decline in the economically very important anchovy fishery in the Black Sea led to undue simplification in the analysis and interpretation of the relationship between the 2 events. 
The major differences in the present nature of the 2 water bodies are due to the fact that the Black Sea is a subsidiary of the Mediterranean Sea, with which it communicates through the Turkish Straits, whereas the Caspian Sea is essentially a huge continental lake, connected with the Black Sea only by the man-made VolgaDon Canal. In the Caspian Sea, a fauna has developed that is largely endemic (Dumont 1998) and may, therefore, be particularly susceptible to external influences. However, viewing the Caspian Sea as a focus of speciation (Dumont 2000), and taking into account the many ecological changes that it underwent in its geological past (with changing water levels leading to temporary connections with the Black Sea and thus to different salinity regimes), it could be that its fauna possess a special adaptability to changing living conditions.

Dumont (www.caspianenvironment.org/mnemiopsis/ mnem_attach17.htm) believes that a catastrophe in the Caspian Sea is almost unavoidable. This author, considering the 1999 findings reported by Ivanov et al. (2000) to represent the first record of Mnemiopsis leidyi in the Caspian Sea, postulated a speedier expansion of the ctenophore in the Caspian Sea than in the Black Sea. He expects $M$. leidyi to 'drive the zooplankton to nearextinction' and to be 'likely to cause havoc' among endemic Amphipoda, Mysidacea and Cumacea. He believes that 'the removal of the zooplankton, and the consumption of pelagic fish-eggs, will severely undermine the pelagic sardine (kilka) populations', and anticipates the 'collapse, and possibly extinction' of the Caspian seal, which will be 'only one out of a of couple hundred species that will be severely affected'.

To make the best possible use of the data gained in the Black Sea, comparable data are needed for the Caspian Sea, above all on the trophic levels of the small pelagic fishes and their staple food, the mesozooplankton, and on the ctenophores and their prey. Intercalibration of sampling techniques and methods of data processing and evaluation is indispensable for obtaining reliable results from such comparisons. From 1999 to 2001 in Azerbaijan and Iran, when very considerable numbers of Mnemiopsis leidyi were already being recorded, the catch of kilka Clupeonella spp., the main small pelagic fish species in the Caspian Sea, decreased by about $50 \%$. To evaluate this observation in the light of the anchovy data for the Black Sea, data on kilka catch fluctuations before this period should be published. Moreover, even severe control of overfishing of kilka in Iran does not necessarily mean that overexploitation of the stocks as a whole can be prevented or halted, since stocks can be shared among several countries.

Rash decisions and premature actions must be avoided since the consequences could be irreparable. The available data suffice for a more differentiated pic- ture. One thing at least can be learned from the Black Sea data: the need for a cautious and balanced approach to data evaluation and management decisions.

\section{CONTROL MEASURES}

The GESAMP report (1997) on the Black Sea covered a whole range of control measures, in particular the introduction of predators on Mnemiopsis leidyi, and considered 2 species as potentially suitable: the ctenophore Beroe ovata and the American butterfish Peprilus triacanthus. Both are known to feed on gelatinous organisms: $B$. ovata only on ctenophores, and $P$. triacanthus mainly on gelatinous organisms including scyphozoans. However, on the one hand, the report saw 'the need for immediate action to reduce the intensity of $M$. leidyi blooms', while on the other hand, it stressed the necessity for 'great caution in any program that involves the introduction of exotic species'. Consequently, further studies were recommended, but not the immediate introduction of a predator. The wisdom of this recommendation is demonstrated by the fact that, at least in offshore waters, the second M. leidyi abundance peak in 1995 was much lower than that in 1989.

Before and at the CEP Workshop in Baku, April 2001 (www.caspianenvironment.org/mnemiopsis/mnen_report. htm), supporters for a biocontrol measure attempted to obtain an early decision, at least in the case of the Caspian Sea. A proposal to introduce the much recommended American butterfish Peprilus triacanthus was dismissed in favour of Beroe ovata. A decisive argument for its deliberate introduction in the event of Mnemiopsis leidyi reaching previously defined critical levels was the assumption that $B$. ovata would eventually arrive in the Caspian Sea on its own accord, along the same route taken by $M$. leidyi. Following this conclusion, experiments were made in 2001 and 2002 to determine whether/how $B$. ovata could be adapted to the waters of the Caspian Sea. So far these experiments, which are still ongoing, have not been conclusive (Kideys et al.: www.caspianenvironment.org/ mnemiopsis/mnemmenu9.htm).

Should the trials to adapt Beroe ovata to Caspian conditions fail because $B$. ovata does not tolerate the same low salinities as Mnemiopsis leidyi, biocontrol advocates could fall back on the introduction of the American butterfish Peprilus triacanthus. However, the assertion that this fish feeds exclusively on gelatinous organisms is questionable. According to FishBase (Froese \& Pauly 2000), finfish also belong to the diet of $P$. triacanthus. At the CEP Workshop in Baku, detailed film sequences (R. Harbison) documented butterfish feeding on gelatinous organisms; however, no other 
food items were offered. It thus remains uncertain what food the butterfish would eat after reducing the abundace of its main prey $M$. leidyi to such a low level that the butterfish begins to starve. Starving butterfish could decimate other finfish species that are valuable as human food. The assumption that the butterfish itself could become a food source for the local human population is also premature. It is well known that the introduction of a fish that in its country of origin is appreciated as valuable human food, into an area where it is unknown can prove a complete failure because of deeply rooted preferences for different species.

When the Turkish anchovy fishery in the Black Sea ceased operating because of lack of fish, the stocks recovered and even gained in strength following the removal of strong fishing pressure, and seemed able to compete successfully with Mnemiopsis leidyi for the available plankton food (Gücü 2002; see also present study Fig. 1). Negarestan et al. (www.caspianenvironment.org/mnemiopsis/mnem_attach13.htm) pointed out that 'more investigation is needed to prove the impact of Mnemiopsis on kilka stocks in the South Caspian Sea', and this should be followed up before introducing new predators. With such a shift in attention, other human-induced changes such as pollution and contamination, eutrophication, and regulation of river runoffs, would also come into focus. Urgently needed is the rational management of the ecosystem and its resources, to support and stabilise their resistance to external influences.

\section{CONCLUSIONS}

The effects of intentional and accidental transfer of organisms from their native to foreign areas are rarely foreseeable. However, excessive reactions in response to fears that the introduction of these new organisms could result in the loss of resources must be avoided. Patience and an increased awareness of less apparent information contained in study results can sometimes prevent undesirable consequences and drawbacks. There is a need for well-orientated research into the current state of resources and their environment, with special regard to trophic relationships. More needs to be known about the susceptibility of these relationships to changes in environmental conditions. More specifically, we need to determine the state of exploitation of the Caspian kilka stocks during the decade preceding the appearance of Mnemiopsis leidyi. Fisheries data that are perhaps only available in the internal reports of fishery authorities and research institutions should be processed and evaluated in order to obtain insight into the kilka stock development preceding the current situation. In addition, the influence of meteoro- logical and hydrological teleconnections on the ecology of the Caspian Sea should receive more attention.

The Caspian Sea area is suffering from ongoing oil pollution from surfacing oil wells and from environmentally hazardous oil rigs dating back to the Soviet era. Research must pay attention also to issues other than those concerning the impact of Mnemiopsis leidyi. Causes of the diseases and mortalities affecting the Caspian seal could perhaps be better understood through a comparison with the population fluctuations in the harbour seal Phoca vitulina in north European waters (Reijnders et al. 1997). While the new research initiative ANGEL (Against iNvasive GELatinous) promoted by ICRAM, a Rome-based Italian institute for marine research and technology, is a worthwhile undertaking, it should take a more balanced approach, also considering concurrent causes of the hazards connected with the invasion of exotic gelatinous organisms.

More specific conclusions that can be drawn from the present review are: (1) There is a need to provide a comprehensive and consistent database for comparison and perhaps extrapolation of research results from the Black Sea to the Caspian Sea. Above all, this should include details of the trophic levels of small pelagic fish species and their staple food, the zooplankton, and of gelatinous organisms and their respective prey. Intercalibration of sampling techniques and methods of data processing and evaluation within the Black Sea, and between the Black and Caspian Seas, is an indispensable prerequisite for obtaining reliable results for comparison and extrapolation. Studies on seasonal population development and trophic relationships should be conducted in areas in which the ecological situation is representative of wider parts of the sea. Results from areas where special conditions such as local current patterns or heavy pollution and contamination prevail could seriously restrict the validity of the findings. (2) It is necessary to strengthen the viability and reproductive capacity of the commercially most important and biologically most vulnerable components of the ecosystem by providing adequate protection, sound management, and assuring sustainable exploitation through appropriate fishery regulations, which apply to all coastal states sharing the resources. In times of unusual stress, such as disturbances in the system due to the invasion or introduction of an alien species, overexploitation of the resources and extreme pollution and contamination should be avoided whenever possible. In periods of increased threat or actual danger, fishing should be strongly reduced or even temporarily suspended. Biocontrol measures, such as the introduction of predators of Mnemiopsis leidyi, should not be taken unless the response of the ecosystem as a whole can be adequately appraised. 
Acknowledgements. The authors are grateful to Dr. A. E. Kideys, Institute of Marine Sciences, Middle East Technical University, Erdemli (Turkey), for placing 2 figures from one of his most recent publications, as well as unpublished information, at their disposal.

\section{LITERATURE CITED}

Bodeanu N (in press) Algal blooms in Romanian Black Sea waters in the last two decades of the XXth century. Cercetari marine - Recherches marines, IRCM 32

CIESM (2001) Gelatinous zooplankton outbreaks: theory and practice. CIESM Workshop Series 14, Monaco; also available at: www.ciesm.org/publications/Naples01.pdf

Cowan VG Jr, Houde ED (1993) Relative predation potentials of scyphomedusae, ctenophores and planktivorous fish on ichthyoplankton in Chesapeake Bay. Mar Ecol Prog Ser 95:55-65

Dumont H (1995) Ecocide in the Caspian Sea. Nature 377: 673-674

Dumont H (1998) The Caspian Lake: history, biota, structure, and function. Limnol Oceanogr 43(1):44-52

Dumont H (2000) Endemism in the Ponto-Caspian fauna, with special emphasis on the Onychopoda (Crustacea). Adv Ecol Res 31:181-196

Finenko GA, Romanova ZA, Abolmasova GI, Anninsky BE, Svetlichny LS, Hubareva ES, Bat L, Kideys AE (2003) Population dynamics, ingestion, growth and reproduction rates of the invader Beroe ovata and its impact on plankton community in Sevastopol Bay, Black Sea. J Plankton Res 25:539-549

Froese R, Pauly D (eds) (2000) FishBase 2000: concepts, design and data sources. ICLARM, Los Baños, Laguna, The Philippines, p 1-344

GESAMP (IMO/FAO/UNESCO/WMO/IAEA/UN/UNEP Joint Group of Experts on Scientific Aspects of Marine Environmental Protection) (1997) Opportunistic settlers and the problem of the ctenophore Mnemiopsis leidyi invasion in the Black Sea. Rep Stud GESAMP 58:1-84

Gordina AD, Niermann U, Kideys AE, Subbotin AA, Artyomov YG (1998) State of ichthyoplankton of the Black Sea and features of its distribution depending on dynamics of waters. In: Ivanov LI, Oguz T (eds) Ecosystem modelling as a management tool for the Black Sea, Book 1. Kluwer Academic Publishers, Dordrecht, p 367-378

Goubanova AD, Prusova IY, Niermann U, Shadrin NV, Polikarpov IG (2001) Dramatic change in the copepod community in Sevastopol Bay (Black Sea) during two decades (1976-1996). Senckenb Marit 31:17-27

Greve W (1981) Invertebrate predator control in a coastal marine ecosystem: the significance of Beroe gracilis (Ctenophora). Kiel Meeresforsch 5:211-217

Gücü AC (1997) Role of fishing in the Black Sea ecosystem. In: Ozsoy E, Mikaelyan A (eds) Sensitivity to change: Black Sea, Baltic Sea and North Sea. Kluwer Academic Publishers, Dordrecht, p 149-162

Gücü AC (2002) Can overfishing be responsible for the successful establishment of Mnemiopsis leidyi in the Black Sea? Estuar Coast Shelf Sci 54:439-451

Gücü AC, Oguz T (1998) Modeling trophic interrelationships in the Black Sea. In: Ivanov LI, Oguz T (eds). Ecosystem modelling as a management tool for the Black Sea. In: NATO-TU Black Sea Project, Book 2. Kluwer Academic Publishers, Dordrecht, p 359-371

Hare SR, Minobe S, Wooster WS (2000) The nature and impacts of North Pacific climate regime shifts. Prog
Oceanogr 47:99-408

Hunter JR, Alheit J (1995) International GLOBEC Small Pelagic Fishes and Climate Change Program. Report of the First Planning Meeting, La Paz, Mexico, June 20-24, 1994. GLOBEC Rep 8:1-72

Ivanov VP, Kamakin AM, Ushivtzev VB, Shiganova T and 5 others (2000) Invasion of the Caspian Sea by the comb jellyfish Mnemiopsis leidyi (Ctenophora). Biol Inv 2:255-258

Kideys AE (2002) The comb-jelly Mnemiopsis leidyi in the Black Sea. In: Leppäkoski E, Olenin S, Gollasch S (eds) Invasive aquatic species of Europe-distributions, impacts and management. Kluwer Academic Publishers, Dordrecht, p 56-61

Kideys AE (2002) Fall and rise of the Black Sea ecosystem. Science 297:1482-1483

Kideys AE, Romanova Z (2001) Distribution of gelatinous macrozooplankton in the southern Black Sea during 1996-1999. Mar Biol 139:535-547

Kideys AE, Moghim M (2003) Distribution of the alien ctenophore Mnemiopsis leidyi in the Caspian Sea in August 2001. Mar Biol 142:163-171

Kideys AE, Kovalev AV, Shulman GE, Gordina AD, Bingel F (2000) A review of zooplankton investigations of the Black Sea over the last decade. J Mar Syst 24:355-371

Konsulov A, Kamburska L (1998a) Ecological determinants of the new ctenophore Beroe ovata invasion in the Black Sea. Proceedings of the Institute of Oceanology of Tarna 2: 195-198

Konsulov A, Kamburska L (1998b) Black Sea zooplankton structural dynamic and variability off the Bulgarian Black Sea coast during 1991-1995. In: Ivanov LI, Oguz T (eds) Ecosystem modeling as a management tool for the Black Sea, Book 1. Kluwer Academic Publishers, Dordrecht, p 281-292

Kovalev AV, Gubanova AD, Kideys AE, Melnikov VV and 6 others (1998) Long-term changes in the biomass and composition of fodder zooplankton in coastal regions of the Black Sea during the period 1954 and 1996. In: Ivanov LI, Oguz T (eds) Ecosystem modeling as a management tool for the Black Sea, Book 2. Kluwer Academic Publishers, Dordrecht, p 209-219

Lasker R (1988) Studies on the northern anchovy: biology, recruitment and fishery oceanography. Studies on Fishery Oceanography, Japanese Society of Fisheries Oceanography: $24-41$

Mills CE (2001) Jellyfish blooms: are populations increasing globally in response to changing ocean conditions? Hydrobiologia 541:55-68

Moncheva S, Krastev A (1997) Some aspects of phytoplankton long term alterations off Bulgarian Black Sea shelf. In: Ozsoy E, Mykaelian A (eds) Sensitivity to change: Black Sea, Baltic Sea and North Sea. Kluwer Academic Publishers, Dordrecht, p 79-94

Mutlu E (1999) Distribution and abundance of ctenophores and their zooplankton food in the Black Sea. II Mnemiopsis leidyi. Mar Biol 135:603-613

Mutlu E, Bingel F, Gücü AC, Melnikov VV, Niermann U, Ostr NA, Zaika VE (1994) Distribution of the new invader Mnemiopsis sp. and the resident Aurelia aurita and Pleurobrachia pileus populations in the Black Sea in the years 1991-1993. ICES J Mar Sci 51:407-421

Niermann U (in press) Mnemiopsis leidyi distribution and effect on the Black Sea ecosystem during the first years of invasion in comparison with other gelatinous blooms. In: Dumont H, Shiganova TA, Niermann U (eds) The invasion of the Black, Mediterranean and Caspian Seas by the American ctenophore Mnemiopsis leidyi Agassiz: a multi- 
disciplinary perspective. Kluwer Academic Publishers, Dordrecht

Niermann U, Bingel F, Gorban A, Gordina AD and 6 others (1994) Distribution of anchovy eggs and larvae (Engraulis enchrasicolus Cuv.) in the Black Sea in 1991 and 1992 in comparison to former surveys. ICES J Mar Sci 51:395-406

Niermann U, Kideys AE, Kovalev AV, Melnikov V, Belokopytov V (1999) Fluctuation of pelagic species of the open Black Sea during 1980-1995 and possible teleconnections. In: Besiktepe S, Ünlüata Ü, Bologa S (eds) Environmental degradation of the Black Sea: challenges and remedies. Kluwer Academic Publishers, Dordrecht, p 147-173

Oguz T, Ducklow HW, Purcell JE, Malanotte-Rizzoli P (2001) Modeling the response of top-down control exerted by gelatinous carnivores on the Black Sea pelagic food web. J Geophys Res 106:4543-4564

Oguz T, Cokacar T, Malanotte-Rizzoli P, Ducklow HW (2003) Climatic warming and accompanying changes in the ecological regime of the Black Sea during 1990s. Global Biogeochem Cycles 17(3):1088

Oliver P (2001) Higher national diploma in fisheries science for Mediterranean countries. Unit 4. Fisheries Management I. Outcome 5: Current fisheries management practices used in the Mediterranean. Part 3.1, Review on the progress of stock assessment studies in the Mediterranean, p 1-12. www.faocopemed.org/vldocs/0000487/hnd_4.5.3.1.pdf

Osoy E, Ünlüata Ü (1997) Oceanography of the Black Sea: a review of some recent results. Earth Sci Rev 42:231-272

Prodanov K, Mikhailov K, Daskalov G, Maxim C, Chashchin A, Arkhipov A, Shlyakhov V, Ozdamar E (1997) Environmental management of fish resources in the Black Sea and their rational exploitation. Studies and Reviews of the General Fisheries Council for the Mediterranean, Rome, FAO 68, p 1-178

Purcell JE, Malej A, Benovid A (1999) Potential links of jellyfish to eutrophication and fisheries. Coast Estuar Stud 55: 241-263

Purcell JE, Shiganova TA, Decker MB, Houde ED (2001) The ctenophore Mnemiopsis in native and exotic habitats: U.S. estuaries versus the Black Sea basin. Hydrobiologia 451:145-176

Reid PC, Edwards M (2001) Long-term changes in the pelagos, benthos and fisheries of the North Sea. Senckenb Marit 31:107-115

Rodionov SN (1994) Global and regional climate interaction: the Caspian Sea experience. Kluwer Academic Publishers, Dordrecht

Reijnders PJH, Ries EH, Tougaard S, Nøgaard N, Heidemann G, Schwarz J, Vareschi E, Traut IM (1997) Population development of the harbour seal, Phoca vitulina, in the Wadden Sea after the virus epizootic. Neth J Sea Res 38:161-168

Seravin LN, Shiganova TA, Luppova NE (2002) Investigation history of comb jelly Beroe ovata (Ctenophora, Atentaculata, Beroida) and certain structural properties of its Black Sea representative. Zool Zh 81 (10):1193-1201 (in Russian)

Shelton PA, Armstrong MJ, Roel BA (1993) An overview of the application of the daily egg production method in the assessment and management of anchovy in the southeast Atlantic. Bull Mar Sci 53:778-794

Shiganova TA (1997) Mnemiopsis leidyi abundance in the Black Sea and its impact on the pelagic community. In: Ozsoy E, Mykaelian A (eds) Sensitivity to change: Black Sea, Baltic Sea and North Sea. Kluwer Academic Publishers, Dordrecht, p 117-131

Editorial responsibility: Otto Kinne (Editor),

Oldendorf/Luhe, Germany
Shiganova TA, Bulganova YV (2000) Effects of gelatinous plankton on Black Sea and Sea of Asow fish and their food resources. ICES J Mar Sci 57:641-648

Shiganova TA, Kamakin AM, Zhukova OP, Ushivtsev VB, Dulimov AB, Musaeva EI (2001a) The invader into the Caspian Sea ctenophore Mnemiopsis and its initial effect on the pelagic ecosystem. Oceanology 41(4):517-524

Shiganova TA, Mirzoyan ZA, Studenikina EA, Volovik SP and 5 others (2001b) Population development of the invader ctenophore Mnemiopsis leidyi in the Black Sea and other seas of the Mediterranean basin. Mar Biol 139:431-445

Shulman G, Yuvena TV (2002) Fishes as indicator of state of the Black Sea and Mediterranean ecosystems. In: Yilmaz AE, Salihoglu I, Mutlu E (eds) Oceanography of the eastern Mediterranean and Black Sea. Abstracts, 2nd International Conference METU, Ankara, p 175

Shushkina EA, Vinogradov ME (1991) Long-term changes in the biomass of plankton in open areas of the Black Sea. Oceanology 31(6):716-721

Stanev EV, Peneva EL (2002) Regional sea level response to global climatic change: Black Sea examples. Global Planet Change 32:33-47

Stone R (2002) Caspian ecology teeters on the brink. Science 295:430-433

Tkach AV, Gordina AD, Niermann U, Kideys AE, Zaika VE (1998) Changes in feeding parameters of fish larvae in the Black Sea during last decade comparing 1950-1960s. In: Ivanov LI, Oguz T (eds) Ecosystem modelling as a management tool for the Black Sea. Book 1. Kluwer Academic Publishers, Dordrecht, p 235-248

Tsikhon-Lukanina YA, Reznitchenko OG (1991) Diet of the ctenophore Mnemiopsis in the Black Sea as a function of size. Oceanology 31:320-323

Tsikhon-Lukanina YA, Reznitchenko OG, Lukasheva TA (1991) Quantitative patterns of feeding of the Black Sea ctenophore Mnemiopsis leidyi. Oceanology 31:196-199

Vinogradov ME, Shuskina EA, Musayeva EI, Sorokin PY (1989) A newly acclimated species in the Black Sea: the ctenophore Mnemiopsis leidyi (Ctenophora: Lobata). Oceanology 29(2):220-224

Vinogradov ME, Shushkina EA, Anokhina LL, Vostokov SV, Kucheruk NV, Lukashova TA (2000) Mass development of the ctenophore Beroe ovata Eschscholtz near the northeastern coast of the Black Sea. Oceanology 40 (1):46-49

Vostokov SV, Arashkevich EG, Dritz AV, Lukashev YF (2001) Ecological and physiological characteristics of the ctenophore Beroe ovata in the coastal waters of the Black Sea: abundance, biomass, size distribution, behavior, feeding, and metabolism. Oceanology 41(1):105-110

Weisse T, Gomoiu MT, Scheffel U, Brodrecht F (2002) Biomass and size composition of the comb jelly Mnemiopsis sp. in the north-western Black Sea during spring 1997 and summer 1995. Estuar Coast Shelf Sci 54:423-437

Yunev OA, Vedernikov VI, Basturk O, Yilmaz Aysen, Kideys AE, Moncheva S, Konovalov SK (2002) Long-term variations of surface chlorophyll $a$ and primary production in the open Black Sea. Mar Ecol Prog Ser 230:11-28

Zaika VE (1993) The drop of anchovy stock in the Black Sea: result of biological pollution? GFCM/FAO Fisheries Report 495, Annex III, p 54-59

Zaitzev YP, Mamaev V (1997) Biological diversity in the Black Sea - a study of change and decline. Black Sea Environmental Series 3, GEF, United Nations Publications, Washington, DC, p 1-208

Submitted: June 4, 2003; Accepted: November 9, 2003

Proofs received from author(s): March 11, 2004 